\title{
ANALISIS FAKTOR-FAKTOR YANG MEMPENGARUHI IMPLEMENTASI BLENDED LEARNING PEMBELAJARAN STATISTIKA BERBASIS PRAKTIKUM DENGAN APLIKASI SOFTWARE SPSS
}

\author{
Slamet Riyanto ${ }^{1}$, Hani Atun Mumtahana ${ }^{2}$ \\ ${ }^{1,2}$ Teknik Informatika Universitas PGRI Madiun, Indonesia \\ 'selamat@unipma.ac.id; ${ }^{2}$ hany_alea03@yahoo.com
}

\begin{abstract}
Abstraks
Tujuan dari penelitian ini adalah untuk mengetahui dan menganalisis faktor-faktor yang mempengaruhi implementasi blended learning mata kuliah statistik berbasis praktikum dengan aplikasi software SPSS. Hasil analisis implementasi dilakukan dengan analisis statistik dengan uji regresi linier berganda dan uji hipotesis dengan uji t. Hasil penelitian ini diketahui bahwa implementasi blended learning pembelajaran statistik dengan metode blended learning berbasis praktikum dengan aplikasi software SPSS secara signifikan dipengaruhi oleh empat faktor, yaitu personal, pengembangan diri, teknologi dan inovasi. Temuan penelitian ini juga menunjukkan bahwa faktor inovasi menjadi faktor yang paling dominan dalam menentukan keberhasilan implementasi pembelajaran statistik.
\end{abstract}

Kata kunci: blended learning, statistik, praktikum

\section{PENDAHULUAN}

Implementasi pembelajaran statistik dengan metode blended learning berbasis praktikum dengan aplikasi software SPSS bertujuan untuk menghasilkan model pembelajaran yang menarik dan efektif. Mengingat bahwa mata kuliah statistik sering dianggap sebagai mata kuliah yang sulit dan membosankan.

Permasalahan yang dihadapi terkait dengan proses pembelajaran mata kuliah statistik tersebut, berusaha diselesaikan dengan metode pembelajaran yang menggabungkan berbagai metode, yaitu dengan metode ceramah dan metode daring. Selain itu, juga diterapkan metode dengan cara menggabungkan antara teori dan praktek aplikasi SPSS untuk mempermudah pemahaman mahasiswa dalam melakukan pengolahan dan analisis data.

Pembelajaran ini diharapkan mampu memberikan solusi untuk meningkatkan hasil belajar mahasiswa dan meningkatkan pemahaman mahasiswa terhadap ilmu statistik. Seperti halnya dengan hasil penelitian yang dilakukan oleh Made (2014), temuan penelitian menunjukkan bahwa pembelajaran statistik membutuhkan e-modul statistika yang terintegrasi dan dinamis. Modul ini akan membantu mahasiswa dalam proses belajar mengajar yang dilakukan secara online maupun konvensional.

Hasil penelitian yang berbeda diperoleh dari penelitian Heny dan Budhi (2011), temuan penelitian menunjukkan bahwa penerapan metode hybrid learning dirasakan kurang sesuai untuk pembelajaran statistik dan pembelajaran statistik lebih tepat dilakukan dengan pembelajaran konvensional.
Mengacu pada hasil penelitian sebelumnya (Riyanto dan Mumtahana (2018)) yang terkait dengan kesiapan blended learning yang ada di program studi Teknik Informatika Universitas PGRI Madiun, dapat dijelaskan bahwa faktor atau dimensi personal memiliki skor rata-rata sebesar 3,3956 yang artinya tidak siap dan dibutuhkan beberapa penambahan. Faktor atau dimensi selfdevelopment memiliki skor rata-rata sebesar 3,3504 yang artinya tidak siap dan dibutuhkan beberapa penambahan. Faktor atau dimensi technology memiliki skor rata-rata sebesar 3,4679 yang artinya siap dan masih dibutuhkan beberapa perbaikan. Faktor atau dimensi innovation memiliki skor ratarata sebesar 3,3086 yang artinya tidak siap dan dibutuhkan beberapa penambahan.

Dapat disimpulkan bahwa dari empat faktor atau dimensi tersebut diketahui bahwa hanya faktor atau dimensi teknologi yang memiliki kesiapan dan masih dibutuhkan beberapa perbaikan. Untuk faktor atau dimensi personal, pengembangan diri dan inovasi dinilai tidak siap dan dibutuhkan beberapa penambahan

Mengacu pada hasil penelitian terdahulu serta sistem pembelanjaran blended learning, maka dihasilkan suatu model desain pembelajaran blended learning (Uwes, 2017) sebagai berikut: 


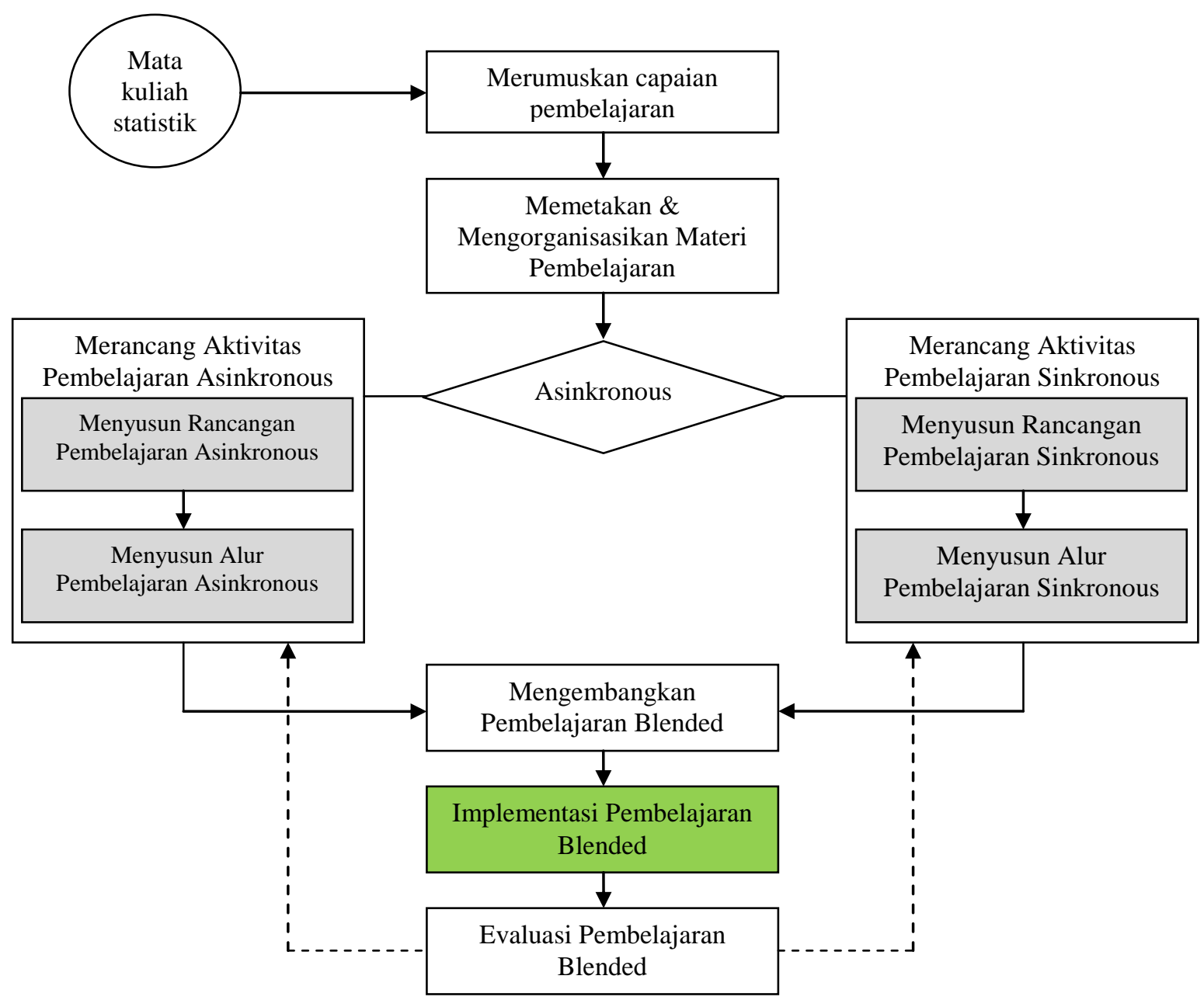

Fokus Penelitian

Gambar 1. Model Desain Sistem Pembelajaran Blended Learning Mata Kuliah Statistik

Dari gambar di atas, menunjukkan pada pada penelitian ini difokuskan pada implementasi pembelajaran blended learning untuk mata kuliah statistik. Implementasi pembelajaran blended learning ini akan dibatasi dengan empat faktor, yaitu faktor personal, pengembangan diri, teknologi dan inovasi, yang dapat digambarkan dengan kerangka pemikiran sebagai berikut:

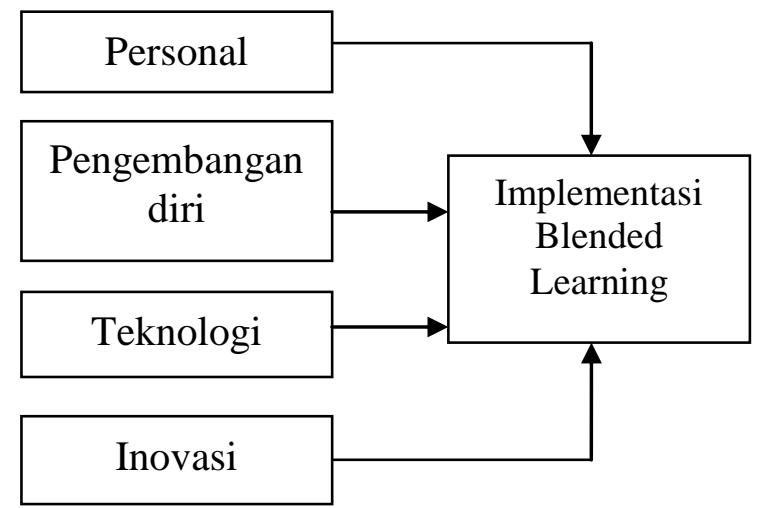

Gambar 2 Kerangka Pemikiran Penelitian Implementasi Pembelajaran Blended

\section{METODOLOGI PENELITIAN}

Penelitian ini dilakukan pada Program Studi Teknik Informatika Universitas PGRI Madiun. Penelitian ini menggunakan metode deskriptif dan analisisnya menggunakan pendekatan kuantitatif dengan tujuan untuk menguji hipotesis.

Sampel penelitian ini adalah mahasiswa tingkat bawah yang telah menerima pembelajaran statistik dengan metode blended learning berbasis praktikum dengan aplikasi software SPSS yang berjumlah 82 mahasiswa. Instrumen yang dipakai berupa kuesioner dengan skala Likert.

\section{HASIL PENELITIAN}

\subsection{Uji Instrumen}

\section{Uji Validitas dan reliabilitas}

Uji validitas digunakan untuk mengetahui layak (valid) dan tidaknya pertanyaan kuesioner yang digunakan dalam pengukuran penelitian. Kriteria keputusannya adalah dengan membandingkan nilai corrected item total correlation $\left(\mathrm{r}_{\text {hitung }}\right.$ ) dengan nilai $\mathrm{r}_{\text {tabel }}$ yaitu $\mathrm{df}=\mathrm{n}-2=(82-2)=80$ diperoleh $\mathrm{r}_{\text {tabel }}=0,217$. Apabila nilai corrected item - total correlation 
lebih besar dari $r_{\text {tabel }}(0,217)$ maka indikator layak (valid) dan sebaliknya.

Tabel 1. Hasil uji validitas

\begin{tabular}{ccc}
\hline Item & \multicolumn{1}{c}{ r hitung } & Keterangan \\
(Indikator) & & \\
\hline \multicolumn{2}{c}{ Faktor personal (X1) } & \\
X1_1 & 0.540 & Valid \\
X1_2 & 0.682 & Valid \\
X1_3 & 0.785 & Valid \\
X1_4 & 0.581 & Valid \\
X1_5 & 0.701 & Valid \\
X1_6 & 0.732 & Valid \\
X1_7 & 0.490 & Valid \\
Faktor pengembangan diri $($ X2) & \\
X2_1 & 0.293 & Valid \\
X2_2 & 0.498 & Valid \\
X2_3 & 0.280 & Valid \\
X2_4 & 0.698 & Valid \\
X2_5 & 0.560 & Valid \\
X2_6 & 0.661 & Valid \\
Faktor teknologi (X3) & \\
X3_1 & 0.674 & Valid \\
X3_2 & 0.676 & Valid \\
X3_3 & 0.701 & Valid \\
X3_4 & 0.713 & Valid \\
X3_5 & 0.751 & Valid \\
X3_6 & 0.615 & Valid \\
X3_7 & 0.619 & Valid \\
X3_8 & 0.442 & Valid \\
Faktor inovasi (X4) & & \\
X4_1 & 0.521 & Valid \\
X4_2 & 0.593 & Valid \\
X4_3 & 0.468 & Valid \\
X4_4 & 0.553 & Valid \\
X4_5 & 0.721 & Valid \\
X4_6 & 0.759 & Valid \\
Implementasi blended learning (Y) \\
Y_1 & 0.454 & Valid \\
Y_2 & 0.599 & Valid \\
Y_3 & 0.793 & Valid \\
Y_4 & 0.729 & Valid \\
Y_5 & 0.750 & Valid \\
Y_6 & 0.729 & Valid \\
Y_7 & 0.694 & Valid \\
\hline & &
\end{tabular}

Berdasarkan uji validitas menunjukkan pertanyaan faktor personal $\left(\mathrm{X}_{1}\right)$, faktor pengembangan diri $\left(\mathrm{X}_{2}\right)$, menunjukkan pertanyaan faktor teknologi $\left(\mathrm{X}_{3}\right)$, faktor inovasi $\left(\mathrm{X}_{4}\right)$ dan implementasi blended learning (Y) semua dinyatakan valid. Hal ini ditandai dengan nilai corrected item - total correlation $\left(r_{\text {hitung }}\right)>r_{\text {tabel }}(0,217)$.

Setelah dilakukan uji validitas, maka langkah selanjutnya adalah melakukan uji reliabilitas yang bertujuan untuk mengukur keandalan instrumen penelitian berdasarkan kelompok variabel penelitian. Suatu variabel dikatakan reliabel jika memberikan nilai cronbach alpha > 0,7. Berdasarkan uji reliabilitas menunjukkan bahwa nilai cronbach alpha sebagai berikut:

Tabe 2. Hasil uji reliabilitas

\begin{tabular}{lll}
\hline \multicolumn{1}{c}{ Variabel } & $\begin{array}{c}\text { Cronbach } \\
\text { Alpha }\end{array}$ & Ket. \\
\hline Personal & 0.868 & Andal \\
Pengembangan diri & 0.750 & Andal \\
Teknologi & 0.880 & Andal \\
Inovasi & 0.795 & Andal \\
Implementasi & 0.887 & Andal \\
blended learning & & \\
\hline \multicolumn{2}{c}{ Hasil uji reliabilitas menunjukkan bahwa } \\
semua nilai cronbach alpha > 0,7; maka \\
instrumen variabel penelitian dinyatakan andal \\
(reliabel).
\end{tabular}

\subsection{Uji Asumsi Klasik \\ Uji normalitas}

Tabel 3. Hasil Uji Normalitas One-SampleKohnogorov-Smimov Test

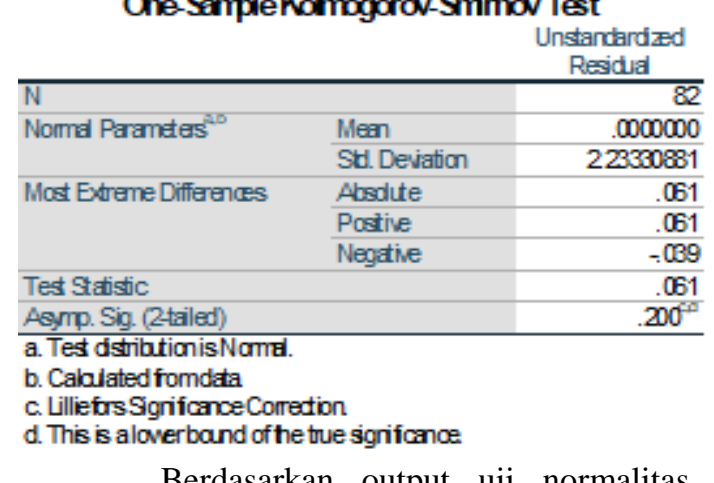
yang terdapat di atas bahwa nilai Assymp Sig sebesar 0,200 lebih besar dari 0,05; dengan demikian dapat dikatakan disimpulkan bahwa data yang akan dianalisis terdistribusi normal.

\section{Uji Autokorelasi}

Tabel 4. Hasil uji autokorelasi

\begin{tabular}{lr} 
Model & Durbin-Watson \\
\hline 1 & 1.842 \\
\hline
\end{tabular}

Berdasarkan output uji autokorelasi di atas nilai DW sebesar 1,842; sedangkan nilai $\mathrm{dl}=$ 1,$541 ; \mathrm{du}=1,745$. Uji autokorelasi di atas menunjukkan bahwa nilai du $<\mathrm{d}<4$-du $(1,745<1,842<2,255)$, artinya tidak ada autokorelasi positif maupun negatif.

Uji multikolinieritas

Tabel 5. Hasil uji multikolinieritas

\begin{tabular}{ll|l|l} 
Model & \multicolumn{2}{c}{$\begin{array}{c}\text { Collinearity } \\
\text { Tolerance }\end{array}$} & VIF \\
\hline 1 & (Constant) & & \\
\cline { 2 - 4 } & Faktor Personal & .459 & 2.181 \\
\hline Faktor Pengembangan diri & .518 & 1.931 \\
\hline Faktor Teknologi & .456 & 2.191 \\
\hline Faktor Inovasi & .466 & 2.145 \\
\hline
\end{tabular}


Berdasarkan output uji multikolinieritas di atas bahwa hasil perhitungan nilai tolerance dari masing-masing variabel independent memiliki nilai toleransi $>0,10$ dan memiliki nilai VIF lebih kecil dari 10. Jadi dapat disimpulkan bahwa tidak ada multikolinieritas antar variabel independent dalam model regresi.

\section{Uji heterokedastisitas}

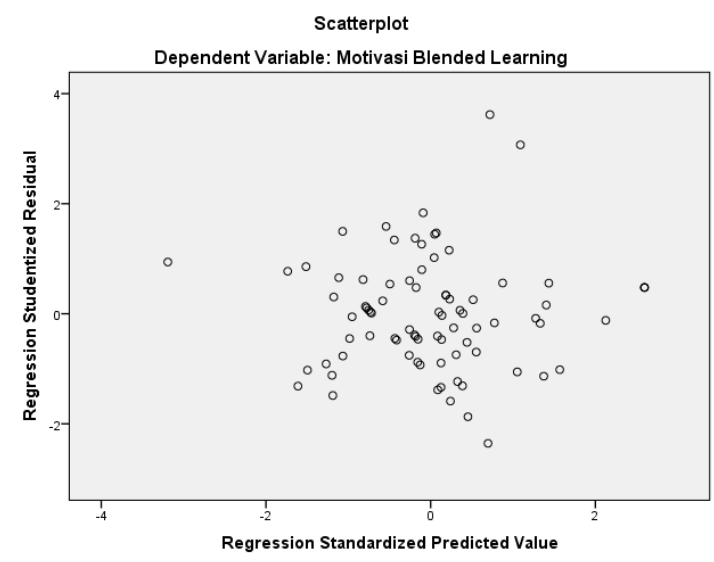

\section{Gambar 4.1 Uji heteroskedastisitas}

Berdasarkan gambar di atas terlihat bahwa tidak ada pola yang jelas, serta titik-titik menyebar di atas dan di bawah adalah angka nol pada sumbu Y, maka model regresi tidak terdapat heteroskedastisitas.

\subsection{Analisis Regresi Linier Berganda} Tabel 6. Analisa Regresi Berganda

\begin{tabular}{|c|c|c|c|c|}
\hline \multirow{2}{*}{\multicolumn{2}{|c|}{ Model }} & \multicolumn{2}{|c|}{$\begin{array}{c}\text { Unstandardized } \\
\text { Coefficients }\end{array}$} & \multirow{2}{*}{$\begin{array}{c}\text { Standardized } \\
\text { Coefficients } \\
\text { Beta }\end{array}$} \\
\hline & & $\mathrm{B}$ & Std. Error & \\
\hline \multirow[t]{5}{*}{1} & (Constant) & -2.886 & 1.981 & \\
\hline & Faktor Personal & .295 & .091 & .286 \\
\hline & Faktor Pengembangan diri & .278 & .117 & .198 \\
\hline & Faktor Teknologi & .185 & .079 & 207 \\
\hline & Faktor Inovasi & .421 & .119 & .311 \\
\hline
\end{tabular}

Dari tabel di depan dapat dijelaskan persamaan regresi linier berganda sebagai berikut :

$$
\begin{aligned}
\mathrm{Y}= & -2,886+0,295 \mathrm{X}_{1}+0,278 \mathrm{X}_{2}+0,185 \mathrm{X}_{3} \\
& +0,421 \mathrm{X}_{4} \\
\alpha & =-2,886 ; \text { menunjukkan besarnya }
\end{aligned}
$$
keberhasilan implementasi blended learning sebelum dipengaruhi faktor personal, faktor pengembangan diri, faktor teknologi dan faktor inovasi.

$\beta 1=0,295$; variabel personal mempunyai pengaruh sebesar 0,295 untuk meningkatkan pelaksanaan blended learning.

$\beta 2=0,278$; variabel pengembangan diri mempunyai pengaruh sebesar 0,278 untuk meningkatkan pelaksanaan blended learning. $\beta 3=0,278$; variabel teknologi mempunyai pengaruh sebesar 0,278 untuk meningkatkan pelaksanaan blended learning.

$\beta 4=0,421$; variabel inovasi mempunyai pengaruh sebesar 0,421 untuk meningkatkan pelaksanaan blended learning.

Dari empat faktor tersebut dapat disimpulkan bahwa faktor inovasi merupakan faktor dominan dalam meningkatkan pelaksanaan blended learning.

\subsection{Uji Parsial (Uji t)}

Uji $t$ ini dilakukan untuk menguji signifikansi pengaruh variabel secara parsial, dengan langkah-langkah sebagai berikut:
a. $\mathrm{H}_{0}: \mathrm{b}_{1 \ldots 4}=0$ artinya, variabel personal, pengembangan diri, teknologi dan inovasi secara parsial tidak berpengaruh terhadap pelaksanaan blended learning. $\mathrm{H}_{\mathrm{i}}: \mathrm{b}_{1 \ldots 4}>0 \quad$ artinya, variabel personal, pengembangan diri, teknologi dan inovasi secara parsial berpengaruh terhadap pelaksanaan blended learning.
b. $\alpha=0,05$ dengan df $(n-k-1)=82-4-1=$ 77; $\quad \mathrm{t}_{\text {tabel }}=1,991$
c. Kriteria pengujian:
1) Bila $\mathrm{t}$ hitung $>\mathrm{t}$ tabel atau sig $<0,05$, maka $\mathrm{H}_{0}$ ditolak dan $\mathrm{H}_{\mathrm{i}}$ diterima.
2) Bila $t$ hitung $<\mathrm{t}$ tabel atau sig $>0,05$ maka $\mathrm{H}_{0}$ diterima dan $\mathrm{H}_{1}$ ditolak.

\section{Tabel 7. Hasil uji t}

\begin{tabular}{llrr} 
Model & $\mathrm{t}$ & \multicolumn{1}{c}{ Sig. } \\
\hline $1 \quad$ (Constant) & -1.457 & .149 \\
& Faktor Personal & 3.232 & .002 \\
& Faktor Pengembangan diri & 2.380 & .020 \\
& Faktor Teknologi & 2.339 & .022 \\
& Faktor Inovasi & 3.544 & .001 \\
\hline
\end{tabular}

Berdasarkan hasil nilai thitung dari faktor personal sebesar 3,232 dan ttabel sebesar 1,991 maka (thitung > ttabel). Kemudian dari tingkat signifikan sebesar 0,002 lebih kecil dari $0,05(0,002<0,05)$ maka H0 ditolak dan H1 diterima. Hal ini berarti bahwa untuk faktor personal secara parsial memiliki pengaruh yang signifikan terhadap pelaksanaan blended learning.

Nilai thitung dari faktor pengembangan diri sebesar 2,380 dan tabel sebesar 1,991 maka (thitung $>$ ttabel). Kemudian dari tingkat signifikan sebesar 0,020 lebih kecil dari 0,05 $(0,020<0,05)$ maka H0 ditolak dan H1 diterima. Hal ini berarti bahwa untuk faktor pengembangan diri secara parsial memiliki pengaruh yang signifikan terhadap pelaksanaan blended learning

Nilai thitung dari faktor teknologi sebesar 2,339 dan ttabel sebesar 1,991 maka (thitung > 
ttabel). Kemudian dari tingkat signifikan sebesar 0,022 lebih kecil dari 0,05 $(0,022<$ 0,05) maka H0 ditolak dan $\mathrm{H} 1$ diterima. Hal ini berarti bahwa untuk faktor teknologi secara parsial memiliki pengaruh yang signifikan terhadap pelaksanaan blended learning

Nilai thitung dari faktor inovasi sebesar 3,544 dan ttabel sebesar 1,991 maka (thitung > ttabel). Kemudian dari tingkat signifikan sebesar 0,001 lebih kecil dari 0,05 (0,001 < 0,05) maka H0 ditolak dan $\mathrm{H} 1$ diterima. Hal ini berarti bahwa untuk faktor inovasi secara parsial memiliki pengaruh yang signifikan terhadap pelaksanaan blended learning

\subsection{Analisis Koefisien Determinasi (R2)}

Uji ini dilakukan untuk mengetahui seberapa besar pelaksanaan blended learning dipengaruhi oleh faktor personal, pengembangan diri, teknologi dan inovasi, berikut hasil uji koefisien determinasi.

Tabel 8. Analisis Koefisien Determinasi

\begin{tabular}{|c|c|c|c|}
\hline Model & $R$ & R Square Adusted R Square & $\begin{array}{l}\text { Std. Error of the } \\
\text { Estimate }\end{array}$ \\
\hline 1 & $.851^{8}$ & $\begin{array}{ll}724 & 710\end{array}$ & 2.29058 \\
\hline
\end{tabular}

Hasil pengujian di atas menunjukkan bahwa nilai koefisien determinasi adalah 0,710 artinya perubahan bahwa pelaksanaan blended learning dipengaruhi oleh faktor personal, pengembangan diri, teknologi dan inovasi sebesar $71 \%$.

\section{KESIMPULAN}

Berdasarkan hasil analisis diketahui bahwa implementasi blended learning pembelajaran statistik dengan metode blended learning berbasis praktikum dengan aplikasi software SPSS secara signifikan dipengaruhi oleh empat faktor, yaitu personal, pengembangan diri, teknologi dan inovasi. Dari empat faktor tersebut yang memiliki kontribusi besar untuk menunjang keberhasilan implementasi blended learning pembelajaran statistik dengan metode blended learning berbasis praktikum dengan aplikasi software SPSS adalah faktor inovasi.

\section{REKOMENDASI}

Untuk meningkatkan berhasilan implementasi blended learning pembelajaran statistik dengan metode blended learning berbasis praktikum dengan aplikasi software SPSS, maka dibutuhkan inovasi dalam pembelajaran. Inovasi pembelajaran ini dapat berupa teknologi pembelajaran berbasis online, inovasi dalam peralatan dan perlengkapan pembelajaran dan inovasi dalam penyajian materi perkuliahan.

\section{PUSTAKA}

Uwes Anis Chaeruman. 2017. PEDATI Model Desain Sistem Pembelajaran Blended. Direktorat Pembelajaran Direktoral Jenderal Pembelajaran dan Kemahasiswaan Kementerian Riset, Teknologi dan Pendidikan Tinggi.

Made I, Tirta. 2014. Pengembangan E-Modul Statistika Terintegrasi dan Dinamik dengan Rshiny dan mathJax. Prosiding Seminar Nasional Matematika, Universitas Jember, 19 November 2014. Hlm. 223-232

Heny, H dan Budhi, P. 2012. Implementasi Model Hybrid Learning pada Proses Pembelajaran Mata Kuliah Statistika II di Prodi Manajemen. Hlm. 181-184.

Riyanto, S dan Mumtahana, HA. 2018. Analysis of Preparedness of Blended Learning in the Informatics Engineering Study Program Environment of the PGRI Madiun University. International Conference on Advanced Computer Science and Information Systems (ICACSIS), hal. xxx-Xxx.

Riyanto, S dan Fatim Nugrahanti. 2018. Pengembangan Pembelajaran Statistika Berbasis Praktikum Aplikasi Software SPSS dengan Bantuan Multimedia untuk Mempermudah Pemahaman Mahasiswa terhadap Ilmu Statistika Jurnal "DoubleClick: Journal of Computer and Information Technology". Volume 1 No.2, Pebruari 2018. hal: 62-67 